\title{
Church proliferation and immorality in Nigeria: Interrogating the paradox
}

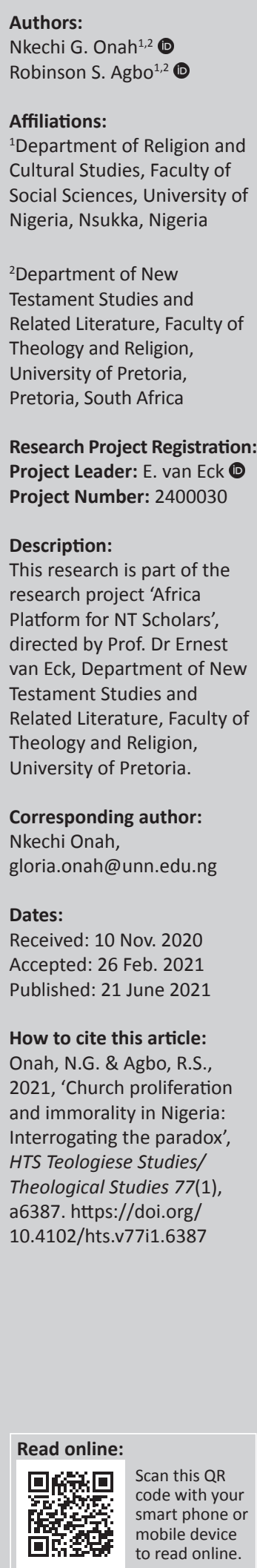

In Nigeria, there is an upsurge in the number of churches. This church proliferation in Nigeria has given rise to the founding of a variety of denominations whilst moral decadence thrives. This article therefore examines the issue of proliferation of churches, its causes and effects on Christianity and the Nigerian society at large. Data for the study were drawn from journals, books and other relevant materials. Employing descriptive narrative approach, this article indicates that the reasons for churches' proliferation include God's calling, unemployment, excessive desire for wealth or greed and leadership tussles. The article argues that despite the positive effects of proliferation of churches, which include socio-economic development, spiritual awakening and evangelism, it also has negative effects such as lack of quality Christian teachings, noise pollution, unhealthy competition and family disintegration. The article suggests that the pastors and ministers of God should receive good training from theological schools for proper interpretation of the Bible and better dissemination of the gospel. They should show good examples to their members and the society at large. It further suggests that noise regulation laws in the country should be enforced.

Contribution: The article examines the issue of proliferation of churches in Nigerian society. In Nigeria, churches are opened in every part of society but Christian religious worship is not being practiced in its true form. Notwithstanding the geometrical increase in churches, other vices have remained unabated in the country.

Keywords: Church proliferation; immorality; Christianity; Pentecostal; Nigeria.

\section{Introduction}

Although Nigeria, a secular state, is home to millions of Christians, Christianity makes up 56\% of the population of Nigeria (Akanbi \& Beyers 2017:1). One of the main problems facing Christianity in Nigeria today is the issue of proliferation of churches. Scholars such as Ugwu (2002), Onyebuagu (2009), Ogbu (2008), and Diara and Onah (2014) acknowledged the proliferation of churches in the 21st century Nigeria. As observed by the World Council of Churches (WCC 2019):

Besides the large mission-founded churches such as the Anglicans, Catholics, Baptists, Methodists, etc., Nigeria has a large number of African Instituted, independent, and Pentecostal churches, which are very active in evangelism and church planting in neighbouring countries, in Europe, North America, and other parts of the world. (n.p.)

Professing the gospel to all people is an injunction by Jesus Christ (Mt 28:19, Mk 16:15). As observed by Ekpendu (2016):

$[I] \mathrm{n}$ the early church the task of teaching (disdasko) required that the truth and the duties of the gospel be more deliberately unfolded and applied ... Its intent was to apply Christ's will to the daily life of the community as a word of instruction, of encouragement, and of consolation, to 'live in Him' (Col. 2:6; 3:16, $\operatorname{Tm} 1$ 6:2, cf. 1 Cor 14: 3; 26). (p. 2)

Followers of Jesus Christ are meant to be 'the salt of the earth' and 'the light of the world' (Mt 5:13-16). Christians are expected to live commendable lives for the growth and development of society. However, according to Onah and Ugwu (2008:70), in Nigeria churches are opened in every part of society but Christian religious worship is not being practiced in its true form. One would expect that the geometrical increase in churches in Nigeria will reflect in the lives of the Nigerian populace but this seems not to be the case. Instead, corruption and other vices have remained unabated in a country where churches are rising on a daily basis. Transparency International (TI) in 2020 released its Corruption Perceptions Index (CPI) of which Nigeria was

Copyright: (C) 2021. The Authors. Licensee: AOSIS. This work is licensed under the Creative Commons Attribution License. Note: Special Collection: Africa Platform for NT Scholars, sub-edited by Ernest van Eck (University of Pretoria). 
ranked 149 out of the 180 countries assessed (Odunsi 2021). Sustainable development remains a mirage for Nigeria. Going by this trend, the questions that readily come to mind are: Why is there geometrical increase in churches in Nigeria? What are the effects on Christianity and society? Focussing on these questions, the article examines the issue of proliferation of churches in Nigerian society. The article employed the descriptive narrative approach. This method concerns the use of indices on ground to describe the phenomenon and also allowing the data to speak for itself.

\section{Trend and growth of Christianity in Nigeria}

Historically, Christianity came to Nigeria in the 15th century through Augustinian and Capuchin monks from Portugal (Haruna 2018:175). Missionary activity in the 15th century was minimal because the overriding commercial interest in slave trade and pepper took prominence (Adamolekun 2012:2). After the abolition of slave trade there was fresh religious enthusiasm amongst the Europeans and Americans (Adamolekun 2012:4). The successful expansion of the Christian missions in Nigeria started in the 19th century with different missionary groups trying to establish their influence (Okpalike \& Nwadialor 2015:16). The first mission of the Church of England was established in 1842 by Henry Townsend in Badagry (Haruna 2018:175). They were followed by other Protestant denominations from Britain, Canada and the United States and in the 1860s by Roman Catholic religious orders (Metz 1991).

Christian religion was one of the instruments that the colonial masters used to win the minds of people in their colonies. The missionaries preached messages of eternity through holiness, condemning worshipping of idols, detestable African customs such as the killing of twin babies, killing people with hunchbacks and human sacrifice (Omonijo et al. 2016:637). Some of the freed African slaves also helped in propagating Christianity. In the late 19th century, some of the freed slaves began to trace their roots back home. Freed slaves from Nigeria moved from Sierra Leone to Lagos and Badagry. Some of them settled in Abeokuta and other cities in western Nigeria (Olulana 2015:n.p.). One of the freed slaves was Samuel Ajayi Crowther who later became the first African to be ordained as bishop by the Christian Missionary Society (CMS) (Olulana 2015:n.p.). In 1853 St. Peter's Church was founded in Lagos by Catechist James White, Reverend Charles Gollmer and Reverend Ajayi Crowther (Olulana 2015:n.p.). Christian Missionary Society churches were established in many towns, such as Abeokuta (1846), Lagos (1851), Ibadan (1853) and Oyo (1856). Offshoots of the CMS church were established in south-eastern Nigeria, with Bonny and Brass as the chief centres (West African Senior School Certificate Examination 2018:100). With time Christianity began to spread and churches were built in different parts of the country.

However, the indigenous people felt that their religious desires were not met by the missionaries and this led to the emergence and growth of Independent Church Movements (Obiefuna, Nwadialor \& Umeanolue 2016). They further quoted Mbefo (2002), thus:

The members of the mainline Churches' expectations from the Churches were not met. The missionaries of the older Churches failed to address the type of questions the African situation raised for them: Witchcraft, demon possession, haunting by evil spirits, the cult of ancestors; the use of protective charms, talisman; sorcery and the traditional dancing form of worship at the shrines. The tendency among the missionaries was to dismiss these questions as due to ignorance arising from a pre-scientific mentality. (p. 29)

Taking a look at contemporary Nigeria, Christianity is undergoing transformation. There is rapid proliferation of churches. There are many Pentecostal churches springing up in Nigeria. It is noteworthy that Pentecostalism has its root in the 19th century Revivalist movement in Topeka, Kansas in the United State of America (Gardner 1998; Melton 2020). Pentecostalism having been influenced by Acts 2:1-13, which speaks of God pouring out his Spirit in the last days, developed into an international missionary activity spreading from North America to Europe and subSaharan Africa (Melton 2020). According to Diara and Onah (2014):

[T]housands of Pentecostal Churches have sprung up in Nigeria since $1970 \ldots$ The fast proliferating independent churches, which are mostly of the new wave firebrand Pentecostal type, began to gain ground across the country in 1986 with the founding of Benson Idahosa's Church of God Mission. (p. 396)

Haruna (2018:175-192) observed that there are over 300000 early Pentecostal Apostolic Churches in Nigeria with about 4.2 million members, including denominations such as the Christ Apostolic Church, the Apostolic Church, the Celestial Church and the Cherubim and Seraphim Church. New Apostolic Christians in Nigeria include the Redeemed Church, Deeper Life Church, Overcomer ministries and other new spring ups (Haruna 2018:175-192). There are also about $380000 \mathrm{New}$ Apostolic Church parishes constituting about 6.5 million believers.

In the view of Fatokun (2016:n.p.), some of these Pentecostal churches started as Christian fellowship centres before metamorphosing into churches, for example, Deeper Life Church, the Redeemed Christian Church, Living Faith (Winners Chapel), Rhema Church, New Testament Church, Church of God Mission, Zoe Ministries, Christ Embassy Church, Latter Rain Assembly and the Dominion Life Bible Church (Fatokun 2016). All the founders of these churches are trying to fulfil the injunction of Jesus Christ that Gospel should be preached to all nations of the world (Mk 16:15).

\section{Reasons for the proliferation of churches in Nigeria}

There are specific factors behind the proliferation of churches in Nigeria. 


\section{God's calling}

God's divine call could be one of the reasons towards church proliferation. Many founders of churches claim that God called them or that they had a revelation to spread the gospel. There are people who resign from good jobs or businesses to start ministry in response to divine call to spread the gospel. Many of them go ahead to establish churches in response to the call. Some still combine their new ministry alongside their jobs or businesses. To buttress this point, John Eze in an interview (11 July 2017) stated that God called him in 1987 when he was at Kano State, Nigeria to go to his town Umuegwu, Neke in Isi-Uzo Local Government Area, Enugu State to start a ministry thereby propagating Christianity. Claiming to have heard the call of God, the founders of this church display spiritual gifts to authenticate their call. This gift is the supernatural ability given by God to a person for teaching, prophecy and healing. Hence, Paul says: 'But to each one of us grace has been given as Christ apportioned'. 'It was he who gave some to be apostles, prophets, evangelist, pastors and teachers' (Eph 4:7 \& 11). Moreover, he declares 'to one ... message of wisdom, knowledge, faith, healing, miraculous powers, prophecy ...' (1 Cor 12:8-10). These are various gifts God gave to his children and in order 'to prepare God's people for service, so that the body of Christ may be built up' (Eph 4:12). Thus, it is the grace of God that gives one the anointing to solve people's problem. In Luke's (Lk 4) gospel, Jesus was quoted as saying:

The spirit of the Lord is on me, because he has anointed me to preach good news to the poor. He has sent me to proclaim freedom for the prisoners, and recovery of sight for the blind, to release the oppressed, to proclaim the year of the Lords favor. (vv. 18-19)

Paul declares in the letter to the Ephesians:

I became a servant of the gospel by the gift of God's grace (anointing) given me through the working of his power .... This grace was given me to preach to the Gentiles the unsearchable riches of Christ (3:7-9).

This spirit leads to evangelism; the gospel of the Lord should be spread to everyone thereby establishing churches to that effect. These gifts are for the edification and building of the body of Christ through the propagation of the gospel. Some pastors organise conventions with thousands of people in attendance. Obiefuna et al. (2016:27) observed that many people go to these gatherings because they find in them answers to their desire for scripture reading, for singing and dancing and emotional contentment.

\section{Unemployment}

One of the obvious reasons why churches are springing up in Nigeria is unemployment. According to Longe (2017:63), a report by National Bureau of Statistics (2016) showed that 52 million Nigerians within the economically active population are unemployed: a figure that is comprised mostly of newly qualified university graduates. Unemployment breeds poverty in the country. Many
Nigerians live in extreme poverty. A total of 86.9 million Nigerians living in extreme poverty represent nearly $50 \%$ of its estimated 180 million population (Kazeem 2018:n.p.). Some poor and unemployed Nigerians see opening of new churches as lucrative business and the easiest way of becoming rich in pretence of divine call (Nmah 2008; Obiefuna et al. 2016), especially those who are eloquent. Going by this trend, it is amazing that within few years of opening a church or ministry, the person starts driving big flashy cars, building mansions, wearing expensive clothes, shoes, watches and so forth. Whilst preaching, their founders stress on offerings, payment of tithe and prosperity with little emphasis on spirituality. Hence, Onah and Ugwu (2008:66) observed that 'the socio-economic decay with the attendant mass sufferings in Nigeria presents a veritable thriving ground for religion as a means of survival'.

In the 1970s and 1980s, church workers were seen as poor people and they were called 'church rats'. The priests or church teachers hardly owned a motorcycle. At that time, nobody wanted to be a church worker. The popular consoling slogan in Igbo language then was, eluigwegaakwuugwo (heaven will pay).

However, the reverse is the case today. Onah and Ugwu (2008) noticed that:

[C]hurches are being opened in all nooks and crannies of the nation, several of which are demonic and evil in practice and their leaders immoral, corrupt and driven by materialism. (p. 70)

Similarly, Onyebuagu (2009:34) observed that 'immoral behaviour, corruption and even rituals and cultism are seen in those new generation churches'. For example, the Daily Post of 25 January 2016, reported that three dead bodies were discovered in a foundation of church under construction in Ugwuaji, Enugu State. According to the report, some residents claimed that the building believed to be a proposed place of worship, belonged to a ritualist who disguised as a man of God. Such people are deviating from spreading the gospel of Jesus Christ to money making.

\section{Excessive desire for wealth and greed}

The getting rich quickly syndrome has penetrated all facets of the Nigerian society. This is evident in politics, social life and even in Christianity. Establishing churches or starting of ministries in the contemporary Nigeria society has been considered as a panacea to poverty and a gateway to wealth. Rather than emphasising spiritual growth, moral sanctity and Christian anticipation of eternal life, signs of total submission to capitalistic inclinations, especially voracious material acquisition looms large in Nigerian churches (Iheanacho 2009). According to Mbefo (2002):

$[I] n$ the recent past, a breed of prophets has sprang up whose message is to realize the hope of heaven here on earth. Their God is neither poor God, nor is he a God of the poor. The sign of God's blessing is the Mercedes car, the impressive mansions or the expensive clothes they wear. They promise to make their followers millionaires. (p. 111) 
Some of these pastors have adopted ostentatious lifestyles and carry themselves as celebrities, superheroes and business executives (Ojo 2018:92). Kuka, in Achunike (2004:44), called them 'harbingers of a "crossless" religion'. Some of these ministers lay emphasis on prophecies, visions, healing, miracles and preach a prosperity gospel. The ministers convince their followers the importance of family deliverance to avert ancestral curses, barrenness, sickness, premature death, poverty and other problems. They capitalise on the poor economic situation in the country and the suffering of the masses. These pastors or ministers de-emphasise the fact that we cannot entirely eliminate sickness and poverty from the world (Mk 14:7). Sickness, suffering and death are parts of being human. Iheanacho (2009) remarked that they:

$[A]$ dvertise for harvest of miracle which would turn out to be harvest of money ... they convince their followers to sow quality seeds and wait for the miracle coming on the way. (p. 104)

They often convince their followers that the more they sow the more blessings will come their way. They go against the injunction in Matthew 10:8, 'Freely you have received, so freely give'. A number of these pastors and general overseers sell stickers, anointing oil, handkerchiefs and wrist bands to their followers. They prey on the myriads of problems existing in the society. They sometimes use television, radio stations, billboards and other social media to advertise their programmes.

Politicians and businessmen who want quick success also patronise these pastors or self-proclaimed evangelists and prophets who claim to be miracle workers. In addition, it has been observed that hardly would one consult such pastors without telling their clients that there is need to conduct deliverance for them and/or sowing of seed. To ensure effective and successful deliverance, some items to be used are to be bought from that ministry. Also, some money should be paid to the man of God before or after the spiritual exercise. In some of these churches, mere seeing or consulting the pastor or evangelist attracts financial charges. Through these, the pastors continue to enrich themselves to the detriment of their gullible congregation. They make merchandise of the gospel.

\section{Leadership tussle and unhealthy rivalry}

Leadership tussle or disagreement between church leaders is tearing and breaking some churches apart in Nigeria and has led to the proliferation of churches. For instance, the church (Assemblies of God) has been involved in leadership tussle for two years, culminating into the emergence of two factional leaders and multiple court actions (The Sun News 20 December 2016).

The church that is supposed to be a place where people gather to worship their God and a place where human beings should be refined and prepared for the second coming of Jesus Christ through the machinery of the word of God sometimes becomes a battle ground. For example, for over two years, Assemblies of God has been in crisis, which landed them in court 'over allegations of misconduct, financial misappropriation and other matters' (Edike in Vanguard 13 April 2014) leading to the eviction of Paul Emeka, the General superintendent, from the secretariat in March 2017 by a section of the church led by his former deputy, Dr Chidi Okoroafor (Nzomiwu Emmanuel in Independent 2019). Paul Emeka later initiated a suit challenging his eviction (Nzomiwu Emmanuel in Independent 2019). This event divided the church into two factions, one led by Prof. Paul Emeka and the other group by Dr Chidi Okoroafor. Rather than settling issues amicably as spiritual men of God, the unhealthy rivalry amongst these leaders of the same church led them to court. This has resulted in the South-South Zone of the Assemblies of God church pulling out of the church 'alleging marginalisation, gross injustice in ministers' remuneration, unhealthy rivalry amongst ministers, inefficiency and escalating administrative and financial malfeasance' (Punch 07 February 2016). From the ongoing discussion, it is obvious that leadership tussle can result in proliferation of churches for every leader has his or her own followers who are ready to form a new church.

\section{Religious doctrinal differences}

Doctrinal differences have been a major factor in the surging cases of the proliferation of churches in Nigeria. The mode of worship and religious teaching of church is based on the doctrine. When a person or a group of persons feel(s) uncomfortable with doctrine being practiced, they decide to form their own church or religious gathering. It is on this basis that Ruth (1993:9) sketched that these specific set of doctrinal tenets form social bases of various churches and para-church organisations in Nigeria.

\section{The effects of proliferation of churches on Christianity in Nigeria}

It is a popular opinion that the proliferation of churches is bad and nothing good comes out of it. But as much as there are negative effects, there are also positive effects of proliferation of churches in Nigeria. It is important to mention here the positive effects before delving into the negative effects of proliferation of Pentecostal Churches in Nigeria.

\section{Positive effects}

These churches have added considerably to the religious and socio-economic growth of Nigeria. Their contributions are discussed in the following sections.

\section{Socio-economic growth}

All the early missionaries started their missionary activities such as building of schools and skill acquisition and so forth alongside other medical services. They started the Western education that has changed the development of Nigeria (Ikeazota 2013:210). These new generation churches, despite spreading the gospel, have also established schools at all levels, hospitals and other economic empowerment facilities for Nigerian citizens. 
Many people have benefited from those projects. It has provided employment and a source of livelihood to those working in such establishments.

Some of the schools established by churches include, for example, Bowen University (owned and operated by the Nigerian Baptist); Covenant University (owned by Living Faith Church); Landmark University (established by Living Faith Church); Benson Idahousa University (owned by Church of God mission); Redeemers University, (owned by the Redeemed Christian Church of God); Rhema University (owned by Living Word Ministry); Hezekiah University (owned by Living Christ Mission); Joseph Ayo Babalola University (owned by Christ Apostolic Church); Mountain Top University (founded by Mountain of Fire and Miracles Ministries) and Anchor University (owned by the Deeper Christian Life Ministry amongst others).

The main line churches are not left out in this laudable venture, which boosts the Nigerian economy. With regard to healthcare services, some of these churches have also established hospitals and other care delivery services to all segments of the society, for example, Healing Stripes Hospital, established in 2010 by the City of David Parish of the Redeemed Christian Church of God, Lagos. They also help in empowering the people for self-reliance. The Love World Skills Acquisition Program of Christ Embassy International (2020), as an example, provides:

[S]pecialized training in online sales and marketing, wigmaking, fashion design, make-over, web design, miniimportation, photography, and video production, intended to empower the beneficiaries to be self-employed and guarded from financial insecurity. (p. 1)

Similarly, the Living Faith Church, also known as Winners Chapel, has mobilised doctors, lawyers, engineers, members of the diplomatic corps, gospel ministers, high ranking government officials and experts from all works of life to various cities outside Nigeria to train mostly the youths and to empower them for self-reliance (Ikeazota 2013:210).

Through these, the churches are contributing not only to the spiritual life of the citizens, but also to human capital development and the development of the society in general.

\section{Spiritual awakening and evangelism}

The emergence of the Pentecostal churches brought spiritual awakening in the mainline churches. Pentecostal churches' emphasis on spiritual gifts, biblical authority and evangelism make them stand out in the society. Most new generation churches are seen carrying megaphones and preaching in different places and converting people, thereby winning more souls for the body of Christ. They try to reach the masses at grassroots level. Their activities have led to the growth of the body of Christ and moral development of individuals.
Their activities give way to spiritual transformation. The mode of worship, in these new generation churches gives the worshippers a sense of belonging and exhibition of emotion. According to Nmah (2008) proliferation of religion (churches) in society caused the mother churches to wake up from spiritual slumber. Similarly, Obiefuna et al. (2016:39) affirmed that proliferation of churches has made the authorities of the mainline churches sit up properly and re-examine their method of operation and sometimes adjust the liturgy to suit the exigencies of the wider society. According to Ojo (2018), the rise of Pentecostal and charismatic movements brought a kind of spirituality into existence, constituting one of the main forms of religion in Nigeria.

\section{Negative effects}

Even though the undaunted commitment of some priests in propagating Christianity is acknowledged, there are some negative effects of proliferation of churches in Nigeria. This is discussed in the following sections.

\section{Lack of quality Christian teachings}

Christianity has been bedevilled by the teachings coming from some pastors, priests and founders of churches. Agbo (2010) stated in this regards that it is:

$[P]$ ainful to note that despite the glaring need of discipleship, most teachings flooding Christendom today are centered [sic] on materialism, self-projection, self-making and avarice. These teachings cannot produce the quality of Christians Christ had in mind when he commanded us to '.. go and make disciples of all nations'. (p. 5)

Much emphasis is laid on prosperity, forgetting that one should 'seek for the kingdom of God first and every other thing shall be added' (Mt 6:33). The New Revised Standard Version of the Bible stated that when Paul saw what was happening amongst Christians in Galatia (Gl 1), he declares:

I am astonished that you are so quickly deserting him who called you in the grace of Christ and are turning to a different gospel not that there is another one, but there are some who trouble you and want to distort the gospel of Christ. (vv. 6-7)

As Onah and Ugwu (2008:66) rightly pointed out, instead of preaching holiness, righteousness, temperance and virtue, pastors focussed their sermons on earthly treasures and material comfort. These teachings are contrary to the word of God. Poverty is neither a crime nor a curse. The poor are special and precious to God. The teachings based on prosperity and breakthrough cannot produce the quality of Christians that bears the mark of Christ.

\section{Moral decadence}

The issue of moral decadence in Nigerian society where churches are springing up in their thousands is worrisome. Christianity that is known with her high moral standard has been bedevilled by immorality. Some pastors have been accused of sexually abusing women and girls. For example, a 
53-year-old pastor of Holy Trinity Ministry Nsukka, Enugu State was arrested for impregnating married women and young girls in his church (Vanguard 26 July 2014). Another example is that of a pastor of Christ Apostolic Church (CAC) who was arrested for repeatedly raping his biological daughter since 2015 in Ogun State. She became impregnated by her father three times and the pregnancies were aborted (Vanguard 08 July 2020), amongst others. Many members of these new generation churches have lost a sense of decency, decorum and virtue. Immodest dressing and immorality are on the increase. Unfortunately, some of these churches have condoned indecent dressing and moral laxity. Many ladies go to church half nude. Men are not exempted from these indecent wears. Some wear tight and saggy trousers, etc. Explanation to this is that the Lord looks at the heart and not at the outward appearance. This explains the reason behind the influx of many youths into such Churches. Christians are expected to be holy (Pt 1 1:15-16) and the life of a Christian should be Christ-like.

\section{Family disintegration}

Another consequence of proliferation of churches in Nigeria is disintegration of families. Some of the Pentecostal churches believe that misfortunes could be caused by witches and wizards who have magical powers to wreak havoc in the lives of people. Many families have been disintegrated because of fake prophecies from some of these prophets who are also founders or general overseers of churches. There are cases where women are accused of being responsible for mishaps on their children. Children are also being accused of witchcraft by some of these prophets. Those accused of witchcraft are seen as causes of misfortune and illnesses such as miscarriages, cancer, human immunodeficiency virus/acquired immunodeficiency syndrome (HIV/AIDS), sudden death, accident and poverty to their family members. Some of those branded witches or wizards are abandoned by their families whilst some are maimed or killed in the process of exorcism by these prophets. These fake prophets exploit especially the ignorant congregants. The Organization for World Peace (2019) stated thus:

The practice of branding children witches has also become a very lucrative one for Pentecostal preachers who are able to 'exorcize' children of the influence of Satan for a price, or as they call it, 'enact deliverances'. In the British Broadcasting Corporation (BBC) documentary Saving Africa's Witch Children, a preacher who calls himself 'the Bishop' says that he personally has killed 110 witches, and now practices deliverances by feeding children a concoction of alcohol, mercury, and his own blood for two weeks, while also pouring a liquid into their eyes and ears. For this, he charges parents 400000 Naira (equivalent to 1108 USD), and if they cannot pay the children are held captive till they can. (n.p.)

The Organization for World Peace (2019:n.p.) further cited Ebe Ukara, a desk officer for the Child Rights Implementation Committee as saying 'even in cases of HIV, these fake prophets will tell a person, "No, it is family witchcraft that is attacking you, so don't go to the hospital, come to my church".' This belief has ruined the unity of many families.
Members of the same family attend different new generation churches than their parents. In a family where some children are worshiping in different churches, there is bound to be disagreements because every one of them will be protecting his own faith or belief.

\section{Unhealthy competition}

The proliferation of churches has brought unhealthy competition amongst the Christian faith. With the upsurge of Pentecostalism, each group struggles for prominence and miraculous power, accompanied by burning and unhealthy competition. Their main aim is to convert the Catholics and main line Protestants who they see as idol worshippers (Obi 2015). This has led to different church leaders erecting church buildings close to each other in order to win more converts. These churches are seen clustered around each other in big cities and urban centres. The members go about sharing fliers to people from other churches inviting them to their conventions and crusades in the quest to win more souls for Christ. Whilst making more converts, they also make more money from the offertory and paying of tithe. The unhealthy competition sometimes leads to strife amongst church ministers and more importantly leads to loss of true evangelism.

\section{Recommendations}

From the given discussion, the following recommendations are made.

1. The ministers of God should receive good training from theological schools for proper interpretation of the bible and better dissemination of the gospel.

2. Church leaders, priests, prophets, evangelists and ministers should imitate Christ whom they claim to have called them and whose priority is to save souls and not make money out of the gospel.

3. The priests, pastors, general overseers, evangelists, prophets and ministers of God should live exemplary lives worthy of emulation. They should shun evil and speak against the moral decadence in the society.

4. The government of Nigeria should enforce registration of the churches springing up in their thousands everyday so that it is only the sincere people who will be in ministry.

\section{Conclusion}

This article has discussed the proliferation of churches in Nigeria. It sees proliferation of churches as a challenge to Christianity. Despite the numerical growth of churches in Nigeria, immorality is unabated in the country. The article highlighted the reasons for the proliferation of churches in Nigeria. It also recognises the positive impact church proliferation has on Nigerian society. It further highlighted the negative effect of proliferation of churches. The word of God has been watered down by the priests or pastors, evangelists and founders of these churches in the quest for money and increased membership. It is on this note that this article argues that in order to preach the gospel as directed by Jesus Christ one should live a holy life worthy of emulation. Pastors and priests should see themselves as 
representatives of Christ on earth; they should avoid engaging in any immoral actions, which may tarnish the image of the church. Christian leaders, priests or pastors, prophets, evangelists, bishops should know that it is important that their lives and preaching should reflect that of Christ from whom Christianity took her name. Unhealthy competition should be minimised.

\section{Acknowledgements Competing interests}

The authors declare that they have no financial or personal relationships that may have inappropriately influenced them in writing this article.

\section{Authors' contributions}

N.G.O. and R.S.A. contributed equally to this research article.

\section{Ethical considerations}

This article followed all ethical standards for research without direct contact with human or animal subjects.

\section{Funding information}

This research received no specific grant from any funding agency in the public, commercial or not-for-profit sectors.

\section{Data availability}

Data sharing is not applicable to this article as no new data were created or analysed in this study.

\section{Disclaimer}

The views and opinions expressed in this article are those of the authors and do not necessarily reflect the official position of any affiliated agency of the authors.

\section{References}

West African Senior School Certificate Examination, 2018, History textbook, viewed 20 May 2021, from https://wasscehistorytextbook.com/.

Achunike, H.C., 2004, The influence of Pentecostalism on Catholic Priests and Seminarians in Nigeria, Rex Charles and Patrick Ltd., Lagos.

Adamolekun, T., 2012, 'Main trends in the church growth in Nigeria', European Scientific Journal 8(23), 1-12.

Agbo, A.E., 2010, Making disciples of all nations, B-i-Fantest Ltd., Lagos.

Akanbi, S.O. \& Beyers, J., 2017, 'The church as a catalyst for transformation in the society', HTS Teologiese Studies/Theological Studies 73(4), a4635. https://doi. org/10.4102/hts.v73i4.4635

Christ Embassy International, 2020, The Loveworld skills acquisition scheme graduates first class in Calabar, viewed 08 April 2020, from https://christembassy.org/ loveworld-skills-acquisition-scheme-graduates-first-class-in-calabar/.

Diara, B.C.D. \& Onah, N.G., 2014, 'The phenomenal growth of Pentecostalism in the contemporary Nigerian society: A challenge to mainline churches', Mediterranean Journal of Social Sciences 5(6), 395-402. https://doi.org/10.5901/mjss.2014.v5n6p395

Ede, R., 2018, 'Assemblies of God: 1 church, 2 headquarters', Daily Sun, 25 March, p.1.

Edike, T., 2014, Trouble in assemblies of God: My case against church leaders, by suspended general superintendent Emeka, Vanguard, viewed 10 March 2019, from https://www.vanguardngr.com/2014/04/trouble-assemblies-god/.

Ekpendu, I.C., 2016, 'The early church and Nigerian Christian church in the postmodern era: An evaluation', Research on Humanities and Social Sciences 6(20), 1-6.
Fatokun, K.O., 2016, 'Assessment of the growth rate of Pentecostal Churches in Oyo town and its implication on Oyo West Baptist association', An essay submitted to the Faculty of the Baptist College of Theology, an affiliate of Nigerian Baptist Theological Seminary, Ogbomosho. In partial fulfillment of the requirements for the award of the degree Bachelor of Theology.

Gardner, S. 1998 'Catholic charismatic renewal fruit of second Vatican, seed of destruction', The Angelus Magazine, viewed 06 April 2020, from http://archives. destruction', The Angelus Magazine, viewed 06 April 2020,
sspx.org/miscellaneous/catholic_charismatic_renewal.htm.

Haruna, S.S., 2018, 'The influence of competitive drive on immorality among church planting ministers in Ejigbo Lagos', African Journal for the Psychological Study of Social Issues 21(3), 175-192.

Iheanacho, N.N., 2009, 'A critical look at contemporary Nigerian Christianity', International Journal of Theology \& Reformed Tradition 1(1), 104-117.

Ikeazota, R.G., 2013, 'Proliferation of churches and national development', BassyAndah Journal 6(1), 207-214.

Independent, 2019, Assemblies of God crisis: Court denies throwing general superintendent out of secretariat, viewed 10 March 2020, from https:// independent.ng/assemblies-of-god-crisis-court-denies-throwing-generalsuperintendent-out-of-secretariat/.

Kazeem, Y., 2018, Nigeria has become the poverty capital of the world, Quartz Africa viewed 19 May 2021, from https://qz.com/africa/1313380/nigerias-has-thehighest-rate-of-extreme-poverty-globally/.

Longe, O. 2017, 'Graduate unemployment in Nigeria: Causes, consequences and remediable approach', American International Journal of Contemporary Research 7(4), 63-73.

Melton, J.G., 2020, Pentecostalism encyclopædia Britannica Inc., viewed 06 April 2020, from https://www.britannica.com/topic/Pentecostalism.

Metz, H.C. (ed.), 1991, Nigeria: A country study, GPO for the Library of Congress, Washington, DC, viewed 07 March 2020, from http://countrystudies.us/nigeria/.

National Bureau of Statistics, 2016, Labor Force Statistics: Unemployment and Underemployment Report, viewed 19 May 2019, from https://www.nigerianstat. gov.ng/pdfuploads/Q2_2020_Unemployment_Report.pdf.

Nmah, P.E., 2008, Religion and society in Africa, Rabboni, Enugu.

Obi, C.C., 2015, Dialogue as an imperative to ecumenical and interreligious problems in Nigeria, Xlibris, Bloomington, IN.

Obiefuna, B., Nwadialor, K.L. \& Umeanolue, I., 2016, 'Costs and benefits of proliferation of Christian denominations in Nigeria', UJAH: Unizik Journal of Arts and Humanities 17(1), 19-44. https://doi.org/10.4314/ujah.v17i1.2

Odunsi, W., 2021, 'Corruption: Transparency International ranks Nigeria 149 on list of 180 countries', viewed 13 February 2021, from https://dailypost.ng/2021/01/29/ corruption-transparency-international-ranks-nigeria-149-on-list-of-180countries/.

Ogbu, K., 2008, African Pentecostalism: An introduction, Oxford University Press, Oxford.

Ojo, M.A., 2018, 'Pentecostalism and charismatic movements in Nigeria: Factors of growth and inherent challenges', The WATS Journal: An Online Journal from West Africa Theological Seminary 3(1), 75-94.

Okpalike, C.J. \& Nwadialor, K.L., 2015, 'The evolution of modern Nigeria through missionary activities within colonial schemata, 1840-1960', viewed 19 May 2021 from https://www.researchgate.net/publication/276270281 The Evolution of Modern_Nigeria_through_Missionary_Activities_Within_Colonial_Schemata_1840-1960.

Olulana, D., 2015, Christianity in Nigeria, viewed 03 March 2020, from https://the234project.com/arts-and-culture/nigeria/christianity-in-nigeria/.

Omonijo, D.O., Nwodo, M.T., Uche, C.O. \& Ezechukwu, N.E., 2016, 'Proliferation of Churches and moral decadence in Nigeria: The socio-economic and religious implications', Scholars Bulletin 2(11), 637-648.

Onah, N.G. \& Ugwu, C.O.T., 2008, 'Prayer as a panacea for human problems: Nigeria Christian experience', Journal of Religion and Human Relations 1(1), 65-75.

Onyebuagu, C.H.E., 2009, Origin, development and theology of Pentecostalism, Darling D Service, Aba, IL.

Punch, 2016, South-South zone pulls out of assemblies of God church, viewed 10 March 2020, from https://punchng.com/south-south-zone-pulls-out-ofassemblies-of-god-church/.

Ruth, M., 1993, 'Pentecostalism in Southern Nigeria: An overview', in P. Clifford (ed.), New dimensions in Africa Christianity, p. 9, Sefer, Ibadan.

The Organization for World Peace, 2019, Child witch-branding and the rise of Pentecostalism across Nigeria, viewed 14 April 2020, from https://theowp.org/ reports/child-witch-branding-and-the-rise-of-pentecostalism-across-nigeria/.

Ugwu, C.O.T., 2002, Man and his religion in a contemporary society, Chuka Educational Publishers, Nsukka.

Vanguard, 2014, God directs me to impregnate married women and their daughtersPastor, viewed 28 October 2020, from https://www.vanguardngr.com/2014/07/ sacrilege-pastor-impregnates-married-women-daughters-says-god-directs/.

Vanguard, 2020, Pastor arrested for raping biological daughter in Ogun, viewed 28 October 2020, from https://www.vanguardngr.com/2020/07/pastor-arrestedfor-raping-biological-daughter-in-ogun/.

World Council of Churches, 2019, Nigeria, viewed 29 December 2019, from https://www.oikoumene.org/en/member-churches/africa/nigeria. 